\title{
Erratum to: Primary and secondary somatic embryogenesis in Chrysanthemum cv. Euro
}

\author{
Aung Htay Naing $\cdot$ Chang Kil Kim • \\ Baek Ji Yun · Jo Yu Jin · Ki Byung Lim
}

Published online: 23 January 2014

(C) Springer Science+Business Media Dordrecht 2014

\section{Erratum to: Plant Cell Tiss Organ Cult (2013) 112:361-368 \\ DOI 10.1007/s11240-012-0243-5}

There were some minor errors to address and supplementary information to supply for the Materials and Methods in the original publication. Those are corrected in the erratum, and the corrected results do not change the outcomes of the study. We apologize for any inconvenience.

Page 362 in the text under heading "induction of somatic embryogenesis", at $22 \mathrm{nd}$ line ' $60-100 \mu \mathrm{mol} / \mathrm{m}^{2} / \mathrm{s}$ ' should be ' $37-40 \mu \mathrm{mol} / \mathrm{m}^{2} / \mathrm{s}$ '.

Page 362 in the text under heading "Secondary somatic embryogenesis" " $1 / 2$ MS" means $1 / 2$ strength of macro and full strength of micro elements.
Page 363 in the text under heading "Plant regeneration and acclimatization", at 5th line 'culture vessel' means 'a square glass bottle which contains five explants'.

Page 363 in the text under heading "Plant regeneration and acclimatization", at the last line 'peat and perlite (1:1)' should be 'vermiculite + peat based soil, 1:1 (v/v)'.

Page 363 in the text under heading "Scanning electron microscope", the sentence "Three samples were examined under scanning electron microscope' should be added after last sentence.

Page 363 in the text under heading "Scanning electron microscope", at the last line 'scanning electron microscope (JOEL, Japan)' should be 'scanning electron microscope (Model: JSM-5410LV, JEOL Ltd., Tokyo, Japan)'.

The online version of the original article can be found under doi:10. 1007/s11240-012-0243-5.

A. H. Naing · C. K. Kim · B. J. Yun · J. Y. Jin · K. B. Lim ( $ه)$

Department of Horticultural Science, Kyungpook National

University, Daegu 702-701, Korea

e-mail: kblim@knu.ac.kr 